\title{
Current Situation and Strategic Suggestions of Physical Education Teachers in Hubei Vocational Colleges
}

\author{
Junhao Zhao, Guanghui Guo \\ Hubei Water Resources Technology College, Wuhan, China (1zhao899@gmail.com)
}

\begin{abstract}
This study used literature survey and questionnaire methods to investigate the age structure, research ability, professional standards, education levels and other aspects of physical education teachers in Hubei Vocational Colleges. The results indicated that the age structure of the faculty in higher vocational colleges in Hubei province is reasonable, but there are still some problems, such as a serious imbalance in the ratio of teachers and students, lower degree of full-time teachers, and lack of scientific research ability. In order to solove these problems, this study came up with several suggestions and strategies to improve the qualification of physical education teachers in vocational colleges.
\end{abstract}

Keywords - Hubei, Higher vocational colleges and universities, physical education teachers, strategy

\section{湖北省高职院校体育师资队伍的现状调查与对策研究}

\author{
赵俊浩郭广辉 \\ 湖北水利水电职业技术学院, 武汉, 湖北, 中国
}

摘 要 本文使用了文献资料调研、问卷调查的方法, 对湖北省高职院校体育教师的年龄结构、科研能力、专业水平、学历层次 等方面进行了调查研究。结果表明, 目前湖北省高职院校体育师资队伍的年龄结构较为合理, 但还存在一些亟待解决的实际问题, 如 在校师生比严重失调体育专职教师队伍学历偏低, 科研能力滞后。针对分析研究中存在的问题提出了完善高职院校师资队伍建设的对策 与建议。

关键词＼cjkstart湖北省，高职院校，体育师资，对策。

\section{1. 研究对象与方法}

\section{1 研究对象}

根据研究目的需要, 本文对湖北省 20 所高职院校 (武 汉市高职院校 12 所，其他地区高校 8 所）体育师资的情况 进行了调查, 力争使所选样本基本覆盖整个湖北省, 体现 湖北省高职院校体育师资的现状。

\section{2 研究方法}

文献资料法: 根据本文研究的需要, 通过查阅图书资 料和中国期刊网获得了大量的文献资料, 为本科研的顺利 进行打下了坚实的基础。

问卷调查法: 为了了解湖北省高职院校体育师资队伍 的现状, 设计了三种问卷, 分别对部分高校体育部门领导、 体育教师和学生进行调查, 并分别对问卷调查进行了信度
和效度检验。反馈表明问卷内容能较全面地反映出高职院 校体育师资的现状, 符合本次研究的任务, 具有较高的信 度和效度。共发放问卷 90 份, 回收 86 份, 回收率为 $95 \%$, 有效率为 $92 \%$ (表 1 )。

表 1 问卷调查情况表

\begin{tabular}{|c|c|c|c|c|}
\hline & $\begin{array}{c}\text { 发放问卷 } \\
\text { 数 }\end{array}$ & $\begin{array}{c}\text { 回收问卷 } \\
\text { 数 }\end{array}$ & $\begin{array}{c}\text { 回收率 } \\
(\%)\end{array}$ & $\begin{array}{c}\text { 有效率 } \\
(\%)\end{array}$ \\
\hline 体育部门领导 & 30 & 30 & 100 & 98 \\
\hline 体育教师 & 30 & 29 & 96 & 95 \\
\hline 学生 & 30 & 27 & 90 & 88 \\
\hline 合计 & 90 & 86 & 95 & 92 \\
\hline
\end{tabular}

数理统计法: 对回收的问卷进行整理, 剔除无效问卷, 
运用统计软件对有效问卷进行数据处理。问卷发放与回收 情况显示如表 1 所示。

逻辑归纳法: 根据调查分析后的数据和资料, 运用逻 辑法进行归纳、推理和总结, 得出结论, 并据此提出建议。

\section{2. 研究结果与分析}

2.1 体育教师人数相对缺乏, 教师队伍的质量和数量是从 事体育教学的基本保证, 是提高体育水平的核心问题。

湖北省高职院校体育教师比例不合理, 体育教师所占 比例少, 个别学校存在着严重的缺编现象（表 2)。

从表 2 可以看出, 从整体上看各个职业院校体育教师 的数量参差不齐, 对于体育教学而言不能满足教学需要。 进入 2000 年后高职高专类院校大规模重组与合并, 目前相 当一部分高职院校是由原来的中专院校升格或合并而成; 同时高职院校大规模扩招, 学生人数剧增, 因此现有体育 教师的数量配备就跟不上时代的发展了。由于体育运动技 术性较强, 如不具备一定条件和科学有效的指导, 学生的 练习就只能处于无序状态, 要达到较高的水平就只能是一 种奢望。另外, 在所了解的高职院校体育教师中, 对应各 体育选项的教师数量不足, 这样使学校开设专项体育的选 修内容受到了限制, 使相当一部分对专项体育感兴趣的同 学流失。

表 2 湖北省高职院校体育教师配备情况调查表

\begin{tabular}{|c|c|c|c|c|}
\hline 教师数量(人) & $3-6$ & $7-10$ & $11-15$ & $>16$ \\
\hline 学校数量(所) & 5 & 8 & 6 & 1 \\
\hline
\end{tabular}

\section{2 体育教师年龄结构较为合理。}

从湖北省高职院校体育师资队伍年龄结构分布情况 (表 3) 可以看出: 年龄从小到大呈正态分布型, 队伍趋 向青中年化。其中 41-50 岁之间的青中年教师人数最多, 为 100 人, 所占比例达 $53 \%$ 。近年来, 随着国家对体育师 资队伍培养力度的不断加强和高校学生人数的增加, 青中 年体育教师人数呈上升趋势, 以青中年体育教师为主体的 中坚力量逐渐活跃在教学第一线上。这批青中年教师大都 身体健康, 精力旺盛, 思想活跃, 有较强的事业心、责任 心和进取精神, 容易接受新生事物, 能适应市场经济的发 展, 给体育师资队伍注入了新的活力。这反映了湖北省高 职院校体育师资队伍后备力量雄厚, 年龄结构较为合理, 已形成老、中、青相结合的格局, 为湖北省高职院校体育 教育事业的发展提供了有利的保证。
表 3 湖北省高职院校体育教师年龄统计表

\begin{tabular}{|c|c|c|c|c|c|}
\hline 年龄 & $20-30$ & $31-40$ & $41-50$ & $>51$ & 总计 \\
\hline 人数 & 34 & 28 & 100 & 26 & 188 \\
\hline 人数比例 & $18 \%$ & $14.8 \%$ & $53 \%$ & $14.2 \%$ & $100 \%$ \\
\hline
\end{tabular}

\section{3 体育教师职称、学历层次偏低。}

教师职称在很大程度上反映了教师的理论水平和发展 潜力。虽然职称与体育教学质量不能划等号, 但体育文化 的表述和教学方式的改革以及教学新模式的引进却与教师 自身的知识水平结构有着密不可分的关系。一般而言, 职 称越高, 对专业的认识越深, 适应教学改革的能力就越强, 那么对体育教育事业的贡献也就越大。近几年来, 随着社 会的进步和教育事业的发展, 高职称化已成为世界各国加 强师资队伍建设的共同趋势。由表 4 可知讲师职称的教师 占了很大的比例——占 $42 \%$, 而副教授职称以上教师人数 极少。教授职称人才缺乏——仅占 $1 \%$, 其中仅有两名教授 也是从本科院校调入。因此, 通过多种渠道提高体育师资 队伍的职称层次, 增加教授的比例, 实现教授比例 “零”的 突破, 应是今后湖北省高职院校师资队伍建设的一个重点。

由表 5 可知, 整体学历层次不高, 博士生学历的教师 为“零”, 研究生比例也仅为 $6 \%$, 本科生占有 $82 \%$, 专科生 $12 \%$ 。其中本科生的比例最大。因此, 加强本科学历的教 师的深造, 通过“同等学历”、“学位办”、“高校教师硕士班” 等形式提升其自身学历层次, 根据本学院职业发展方向适 当的引进博士学历的体育教师, 实现“零”的转变。

表 4 湖北省高职院校体育教师职称情况调查表

\begin{tabular}{|c|c|c|c|c|c|}
\hline 职称 & 教授 & 副教授 & 讲师 & 助教 & 总计 \\
\hline 人数 & 2 & 60 & 79 & 48 & 188 \\
\hline 人数比例 & $1 \%$ & $32 \%$ & $42 \%$ & $25 \%$ & $100 \%$ \\
\hline
\end{tabular}

表 5 湖北省高职院校体育教师学历情况调查表

\begin{tabular}{|c|c|c|c|c|c|}
\hline 学历 & 博士 & 研究生 & 本科 & 专科 & 总计 \\
\hline 人数 & 0 & 12 & 154 & 22 & 188 \\
\hline 人数比例 & 0 & $6 \%$ & $82 \%$ & $12 \%$ & $100 \%$ \\
\hline
\end{tabular}

2.4 高职院校体育科研能力滞后。

体育教师科研能力滞后, 体育科研工作是体育学科建 设的基础, 也是完成好教学、群体活动、训练竞赛等各项工 作的有利保障, 更是提高教师素质的有效途径。高校进行 
体育教育活动, 要求任课教师除了具备专业技能以外, 还 必须具备相关专业的科研能力, 以科研带动教学, 更好地 投身于教学改革, 形成科研和教学之间的良性互动。本文 对湖北省 20 所高职院校体育系（部） 188 名体育教师近 5 年的科研情况进行了调查, 调查的结果显示: 公开发表体 育专业方面论文的总数为 211 篇; 其中省级刊物发表 127 篇, 内部刊物 46 篇, 核心期刊发表 38 篇。总体表现为科 研滞后, 学术研究气氛不浓厚。从公开发表论文和参与课 题研究的数量和层次来看, 副教授成果最多, 其次为讲师。 助教的科研能力最为薄弱, 这一方面与助教参加工作年限 少, 理论、经验还有所欠缺有关, 另一方面也和缺乏科研 意识有很大的关系。年轻教师是将来承担体育教学改革、 科研的生力军, 加大对他们科研能力的培养和强化科研意 识是一个不容回避的现实。在调查中, 发现了一个值得警 觉的问题, 在近 5 年来没有科研成果的教师队伍中, 副高 级职称教师占了一定的比例。通过访谈得知这一部分教师 认为搞科研费时、费力、费钱,特别是专业核心期刊上发表 文章就更加困难。另外, 在职称上再上一个级别难度太大, 因此放弃了科研上的努力, 这种思想具有一定的普遍性, 应该引起有关部门的高度重视。

\section{3. 建议}

加强对高职称、高学历、经验丰富的体育师资的引进 和培养, 合理配置教师专业比例, 高职院校各级领导要努 力为年轻教师的成长创造有利条件, 一是对高校现有教师 队伍进行体育专项业务培训, 提高体育教师的理论和技术 水平; 其次是鼓励他们外出进行硕、博学习, 攻读高层次 学位, 争取实现高职院校体育教师队伍的研究生化。同时, 高职院校要根据学校的事业发展, 规划对体育教师数量需 求的变化以及专业结构的调整具有前瞻性的实施方案。目 前湖北省平均每所高职院校有体育教师 5-7 人, 这对于开 展专项体育教学和阳光体育运动是远远不够的。高校应积 极引进高学历、高职称的人才补充现有的体育师资队伍, 应根据学校规模招生人数按比例合理配置体育教师人数,
根据学校专业特点, 师资和场地器材合理安排体育专项教 师。

加强与体育院校的横向联系, 为高职院校储备高规格 的师资人才, 高职院校体育师资来源主要是各体育院校、 系体育专项的学生, 同时由于高职院校教学的需要, 其他 体育专业的学生也是潜在的来源, 因此高职院校应加强与 体育高校的联系, 经常关注体育院校的专业情况, 根据学 院专业素质为学生终生体育, 及时调整公共体育普修教学 的内容和形式, 做好高职院校体育教师人才的储备工作。 同时高职院校也需要加强与体育专业院校的横向联系, 多 形式、多渠道开办高职院校体育师资培训，把师资培训作 为一项长期工作来抓。

量化科研指标，促进体育师资科研能力的提高。目前 湖北省高职院校体育教师科研能力总体水平较低, 相关部 门应制定完善的科研制度,实行科研成果量化指标，促进现 有体育教师重视科学研究, 以科研促进教学质量的提高, 对科研经验不足的青年体育教师可实行导师制, 落实培养 导师，逐一进行传、帮、带, 切实提高年青教师的科研水 平。

\section{参考文献(References)}

[1] Wang Xiao-dong, Gao Hang, Martial Art and School Education: A History Review, Journal of Captial Institute of Physical Education, vol.16, 2004.

[2] Zhang Yao-ting, The history of Chinese Martial Arts, People's Sports Publishing House of China, Beijing, 1997

[3] Wang Jian-hua, Zhou Qing-jing, Present Situation of Public Wushu Course in Colleges and Universities and its Developing Countermeasures, Journal of Shenyang Institute of Physical Education, vol.23, 2004.

[4] Liang Ya-dong, LIU Guo-li, Qu Run-jie, Study on Present and Strategy of Wushu Teachers in Colleges and Universities of Hubei Province. Journal of Shengyang Sport University, vol. 26, 2007. 